\title{
Marketing channel, margin, and price behavior of egg in selected areas of Gazipur district
}

\author{
M. I. Omar ${ }^{1}$, S. A. Sabur ${ }^{2}$, M. Moniruzzaman ${ }^{3^{*}}$ and M. S. Hoq ${ }^{4}$ \\ ${ }_{1 \& 4}$ Agricultural Economics Division, Bangladesh Agricultural Research Institute and ${ }^{2 \& 3}$ Department of Agribusiness \\ and Marketing, Bangladesh Agricultural University, Mymensingh-2202, Bangladesh, *E-mail: zamanbau@yahoo.com
}

\begin{abstract}
The present study was undertaken to examine the marketing channel, marketing margin, seasonal price variation, problems and probable solutions of egg marketing in Gazipur district. The sample size of the study was 55 which included 15 layer farm owners and 40 egg traders selected purposively. Data were collected from both primary and secondary sources. In egg marketing system five different channels were identified. The average marketing costs for layer farm owner, arathder, wholesaler, wholesaler cum retailer and retailer were Tk. 3.23, Tk. 20.60, Tk.16.34, Tk.13.09 and Tk. 12.51 per 100 eggs, respectively. The net marketing margins for arathder, wholesaler, wholesaler cum retailer and retailer were estimated at Tk. 9.40, Tk.13.60, Tk. 21.91 and Tk. 32.50. Price was the highest in the month of July and lowest in the month of December. There was a wide seasonal price variation of egg in the selected markets due to change in demand and supply at different times of the year. The study identified some problems of layer farming and marketing of egg, and suggested measures for solving these problems.
\end{abstract}

Keywords: Marketing channel of egg, Marketing margin, Price behavior, Gazipur district

\section{Introduction}

Bangladesh is a densely populated developing country of 147570 sq. km (BBS, 2000) area with about 145.2 million people (GOB, 2010). The economy of Bangladesh mostly depends on agricultural resources. Approximately eighty five per cent people of the country rely on agriculture in one way or other for their livelihoods. Livestock is an important sub-sector of Bangladesh's agriculture, of which contribution of poultry has risen significantly. The share of livestock sub-sector to total agricultural GDP has increased from 12.72 per cent in 2000-01 to 14.30 per cent in 2009-10 (at current price) in Bangladesh (MoF/BER, 2011). Poultry production and poultry related industry contribute 20.65 per cent of the total livestock contribution (Khan and Roy, 2006).

Poultry industry is the most vital for its key contributions to national economy in the spheres of generating employment, creating additional income and improving the nutritional level of this country and egg is one of the main products of poultry farming.

Commercial layer farming is not only a source of employment, income and food but also critical to strong socio-cultural linkage in a country like Bangladesh. The demand for egg is increasing with the rapid increase in population. To meet up the increasing demand, apart from egg production, efficient egg marketing is necessary. It is difficult to run a profitable business without proper and organized marketing system. Therefore, marketing is a very important factor for egg as a commercial product. An efficient marketing system is needed for availability of product supply at a fair price and to encourage higher production. For this reason, it is essential to observe the present marketing system, to identify the problems and to improve the marketing system of egg in Bangladesh.

The study has provided valuable information for the egg producers, traders and other concerned people in Bangladesh to take appropriate decisions regarding further expansion of commercial layer farming and trading. The study has provided information for the policy makers, planners and other concerned agencies to formulate policy for the improvement in marketing system of egg in Bangladesh. The study covered the marketing system of egg and price behavior of egg in selected areas. Further, the study attempted to identify some basic problems of egg marketing that are faced by the traders and to provide measures for probable solutions. The study also made recommendations for policy measures for improvement of egg marketing with a view to achieving efficiency by analyzing the present marketing problems. Lastly, it will add new knowledge for the researchers to conduct further research on these lines. So the specific objectives of the study were

i. $\quad$ To determine the marketing costs and margins of egg in different channels.

ii. To analyze seasonal price variation and

iii. To identify the problems of egg production and marketing and suggested measures for improvement of egg marketing. 


\section{Materials and Methods}

The present study is based on primary and secondary data. The survey method for the present study involved the following steps:

\section{Selection of the study area}

The study was conducted in Shreepur Upazila and different markets in Gazipur district for collecting farm and trader's level data, respectively. Dhaka, Gazipur, Rajshahi, Chittagong, Sylhet, Khulna and Mymensingh districts markets were also considered for analyzing seasonal price variation.

\section{Selection of sample and sampling technique}

For the different stages of egg marketing, samples of egg farmers and traders were purposively selected in order to meet the objectives of the study. The total sample size was 55 of which 15 egg farmers, 6 arathder, 10 wholesalers, 5 wholesaler cum retailers, 16 retailers and 3 faria were selected for interviewing from the study area.

\section{Collection of data}

The data were collected both from primary and secondary sources for the study. Primary data were collected by the researcher himself in the month of September in 2011 through face to face interview with the selected respondents in the study area. Farm level primary data were collected from Shreepur Upazila of Gazipur district and traders level primary data were collected from five market (Gazipur market, Mauna bazar, Bourt bazar, Sreepur bazar and Tongi bazar) of Gazipur district. Secondary data were also accumulated from FAO publication, official records, books, journals and from the various statistical year books. The weekly average wholesale prices of eggs of various markets like Dhaka, Gazipur, Rajshahi, Chittagong, Sylhet, Khulna and Mymensingh from 2000 to 2010 were collected from Department of Agricultural Marketing (DAM). Latter it was converted into monthly figures.

\section{Analytical technique}

Depreciation method was used for determining the cost of cage. For estimating seasonal price variation ratio to moving average method was used. Marketing efficiency was determined by Acharya's methods (Acharaya and Agarwal, 1999).

Cage cost:

$\mathrm{DC}=\frac{\text { (Beginning }- \text { Salvage) Value }}{\text { Time }}$

$\mathrm{DC}=$ Depreciation cost.

$>$ Marketing margin= Selling price - Purchase price

$>$ Net marketing margin= Marketing margin- Marketing cost

For estimating seasonal price variation ratio to moving average method was used.

\section{Results and Discussion}

\section{Marketing Channels of Eggs}

The main aim of layer farming is to earn profit by placing the eggs at the disposal of the consumers. It involves a number of important activities at different stages which are performed by a series of intermediaries, linking the producers with the consumers. The marketing channels of eggs as found in the study areas are shown in Fig. 1.

\section{Marketing cost and margin}

Marketing cost of layer farm owner: An estimation of the cost of marketing of the layer farm owners would be made in this section. Layer farm owners performed the function of selling egg to arathder at farm. Total marketing cost incurred by the farm owners for 100 eggs was calculated at Tk. 3.23 (Table 1). The major components for cost were wastage, cage, telephone bill and personal expense. 


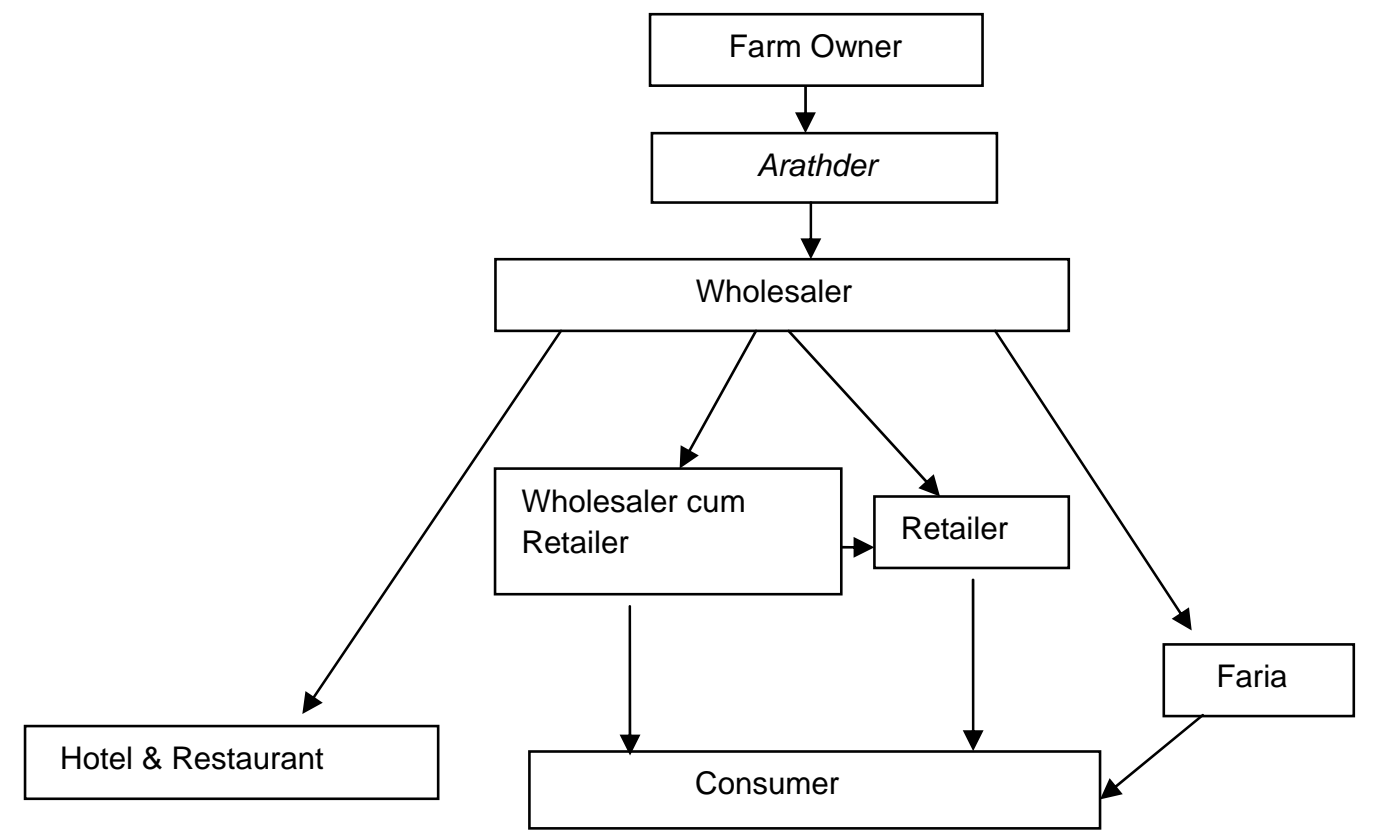

Fig. 1 Marketing channels of egg in Gazipur district

Table 1. Marketing cost of layer farm owners

\begin{tabular}{|l|c|c|}
\hline Cost item & Cost (Tk./100 Eggs) & Percentage \\
\hline Wastage & 2.05 & 63.47 \\
Telephone bill & 0.35 & 10.83 \\
Personal expense & 0.45 & 13.93 \\
Cage & 0.38 & 11.75 \\
\hline Total & 3.23 & 100.00 \\
\hline
\end{tabular}

Total marketing cost of egg intermediaries: Nature and extent of marketing cost varied from trader to trader. The total cost of marketing of egg included all costs incurred by different types of intermediaries operated between the producers and consumers. Table 2 shows the total marketing cost of egg for all intermediaries. For one hundred eggs, average costs for arathder, wholesaler, wholesaler cum retailer and retailer were Tk. 20.60, Tk. 16.34, Tk.13.09, and Tk. 12.51 respectively. The total marketing costs incurred by all intermediaries were calculated at Tk. 62.54 per hundred eggs. Transportation cost was the highest cost which was 37.26 percent of the total marketing cost. The second largest cost item was rent of shop which was 14.13 percent of total marketing cost.

Table 2. Marketing cost of intermediaries (Tk. per 100 eggs)

\begin{tabular}{|l|c|c|c|c|c|c|}
\hline Cost item & Arathder & Wholesaler & Wholesaler cum retailer & Retailer & Total & Percentage \\
\hline Transport & $8(38.83)$ & $6(36.71)$ & $4.8(36.50)$ & $4.5(35.98)$ & 23.3 & 37.26 \\
\hline Rent of the shop & $2.89(14.05)$ & $2.4(14.68)$ & $1.98(15.12)$ & $1.56(12.47)$ & 8.83 & 14.13 \\
\hline Salary & $2.93(14.24)$ & $2.16(13.22)$ & $1.43(10.89)$ & $1.36(10.87)$ & 7.88 & 12.60 \\
\hline Electricity & $1.86(9.01)$ & $1.53(9.35)$ & $0.95(7.22)$ & $0.69(5.48)$ & 5.02 & 8.02 \\
\hline Market tool & $0.53(2.57)$ & $0.43(2.63)$ & $0.42(3.22)$ & $0.32(2.56)$ & 1.70 & 2.72 \\
\hline Wastage & $1.96(9.50)$ & $1.9(11.63)$ & $1.96(14.97)$ & $1.9(15.22)$ & 7.72 & 12.34 \\
\hline Market security & $0.53(2.55)$ & $0.42(1.59)$ & $0.25(1.93)$ & $0.15(1.22)$ & 1.35 & 2.16 \\
\hline Telephone & $0.57(2.76)$ & $0.53(3.22)$ & $0.25(1.87)$ & $0.16(1.25)$ & 1.50 & 2.39 \\
\hline Personal & $0.76(3.67)$ & $0.66(4.01)$ & $0.46(3.49)$ & $0.2(1.60)$ & 2.07 & 3.31 \\
\hline Cage & $0.5(2.43)$ & $0.3(1.84)$ & $0.24(1.85)$ & $1.52(12.15)$ & 2.56 & 4.10 \\
\hline Loading and unloading & $0.03(0.12)$ & $0.02(0.12)$ & - & - & 0.05 & 0.07 \\
\hline Miscellaneous & $0.06(0.24)$ & - & $0.36(2.77)$ & $0.15(1.20)$ & 0.57 & 0.91 \\
\hline Total & 20.60 & 16.34 & 13.09 & 12.51 & 62.54 & 100 \\
\hline
\end{tabular}

*Figures in the parentheses indicate percent of total within each intermediary 
Marketing Margin: The portion of consumer's price that goes to marketing intermediaries is referred to as the marketing margin. The total marketing margin usually consists of margins at different stages of marketing and in each case the margin is the difference between the buying and selling prices of each intermediary (Patniak, 1989). According to Tomek and Robinson (1990), marketing margin may be defined alternatively as (i) a difference between the price paid by the consumers and that obtained by producers or as (2) the price of a collection of marketing services which is the outcome of the demand for and the supply of such services.

In this section both gross and net marketing margin of eggs were calculated separately for different intermediaries. Gross marketing margin was calculated by subtracting the value of purchase of eggs from their value of sales proceeds and net margin (profit) was calculated by subtracting the total marketing cost of eggs from the gross margin. Marketing margin of different intermediaries of eggs is shown in Table 3.

Table 3. Marketing margin of intermediaries (Tk. / 100 eggs)

\begin{tabular}{|l|c|c|c|c|c|}
\hline Intermediaries & Purchase Price & Sale price & Marketing margin & Marketing cost & Net marketing margin \\
\hline Arathder & 570 & 600 & 30 & 20.60 & 9.40 \\
\hline Wholesaler & 600 & 630 & 30 & 16.34 & 13.60 \\
\hline Wholesaler cum retailer & 630 & 665 & 35 & 13.09 & 21.91 \\
\hline Retailer & 635 & 680 & 45 & 12.50 & 32.50 \\
\hline
\end{tabular}

Table 3 indicates that the gross marketing margins of arathder, wholesaler, wholesaler cum retailer and retailer were Tk. 30, Tk.30, Tk.35 and Tk. 45 and net marketing margins were Tk. 9.40, Tk. 13.60, Tk. 21.91 and Tk. 32.50 respectively for 100 eggs. The net marketing margin of retailer was higher than that of other intermediaries because of their higher gross marketing margin and cost of lower marketing cost as compared to that of other intermediaries.

\section{Marketwise seasonal price variation of eggs}

Dhaka market: The monthly average wholesale price indices of egg during the period of 2000 to 2010 in Dhaka market have been presented in Table 4. It is observed that highest price index was 105.41(i.e; price becomes 5.41 percent higher than average price) in the month of July and the lowest of 95.12 (i.e; price goes down about 4.88 percent than average price) in the month of December. The difference between highest and lowest indices of egg was 9.53 and the co-efficient of variation of monthly price indices 3.16 in Dhaka market.

Chittagong market: It is evident from Table 4 during 2000 to 2010, seasonal index of egg price in Chittagong market was the highest in the month of July and that was 106.83 and the lowest seasonal price index was 95.11 in the month of December. During July to October the indices remained above average, while they remained below average during the rest of the year. The difference between highest and lowest indices was 11.72. The co-efficient of variation of monthly price indices of egg in Chittagong market was 3.81. Price fluctuation of eggs in Chittagong market is greater than other studied market because coefficient of variation is higher.

Rajshahi market: It is evident from Table 4 that during 2000 to 2010, seasonal index of egg price in Rajshahi market was the highest in the month of July and that was 106.46 and the lowest seasonal price index was 94.92 in the month of December. Table 4 also showed that the difference between highest and lowest indices was 11.54. The co-efficient of variation of monthly price indices of egg in Rajshahi market of that period was 3.18 .

Khulna market: The seasonal price indices of egg during 2000 to 2010 in Khulna market are shown in Table 4. It is observed that seasonal index of egg price of 106.46 was the highest in the month August and the lowest of 94.92 in the month of December. The difference between highest and lowest indices of egg in Khulna market was 11.58 and co-efficient of variation of monthly seasonal index was 3.18. Price fluctuation of egg in Khulna and Rajshahi market is lower than other studied market. 
Mymensingh market: It is evident from Table 4 that during 2000 to 2010 , seasonal index of egg price was the highest in the month of July and that was 106.79 the lowest was 94.29 in the month of November. Price of egg fluctuated in different months. The cause of this fluctuation might be due to the change in demand in different months. Table 4 also showed that the difference between highest and lowest indices was 12.50. The co-efficient of variation of monthly price indices of egg in Mymensingh market of that period was 3.18.

Sylhet market: The monthly average wholesale price indices of egg in Sylhet market have been presented in Table 4. The price index of egg was the highest (106.17) in the month of August and the lowest of (95.89) in the month of November. The difference between highest and lowest indices was 10.28 and the co-efficient of variation of price indices was 3.33.

Gazipur market: The monthly average wholesale price indices of egg in Gazipur market have been presented in Table 4 the price index of egg was the highest (106.12) in the month of July and the lowest (94.73) in the month of December. The difference between highest and lowest indices was 11.39 and the co-efficient of variation of price indices was 2.75. A study on price behavior and marketing of egg and found that winter was the highest egg producing season for all farmers.

Table 4. Seasonal price variation of eggs in different market

\begin{tabular}{|l|c|c|c|c|c|c|c|c|c|c|}
\hline Market & Dhaka & Chittagong & Rajshahi & Khulna & Sylhet & Mymensingh & Gazipur & $\begin{array}{c}\text { Average of seven } \\
\text { market }\end{array}$ \\
\hline Month & \multicolumn{9}{|c|}{ Seasonal price variation of egg in selected market } \\
\hline January & 99.77 & 97.92 & 98.33 & 96.57 & 98.76 & 97.06 & 98.78 & 98.17 \\
\hline February & 97.27 & 97.88 & 100.43 & 100.43 & 96.36 & 104.15 & 100.71 & 99.6 \\
\hline March & 96.15 & 95.28 & 96.57 & 98.33 & 97.54 & 96.94 & 97.31 & 96.87 \\
\hline April & 101.61 & 99.11 & 100.27 & 100.27 & 102.39 & 101.9 & 99.25 & 100.4 \\
\hline May & 99.97 & 97.31 & 99.18 & 99.18 & 99.62 & 99.65 & 100.07 & 99.28 \\
\hline June & 98.52 & 97.77 & 99.74 & 99.74 & 97.76 & 100.93 & 99.11 & 98.86 \\
\hline July & 105.47 & 106.83 & 106.4 & 104.48 & 104.55 & 106.79 & 106.12 & 105.88 \\
\hline August & 102.51 & 106.29 & 104.48 & 106.46 & 106.17 & 104.12 & 102.35 & 105.34 \\
\hline September & 101.41 & 102.93 & 99.54 & 99.54 & 100.69 & 97.91 & 100.37 & 100.34 \\
\hline October & 104.17 & 101.81 & 102.04 & 102.04 & 102.79 & 100.72 & 101.18 & 102.11 \\
\hline November & 98.03 & 101.74 & 98.03 & 98.03 & 95.89 & 94.29 & 99.03 & 97.86 \\
\hline December & 95.12 & 95.11 & 94.92 & 94.92 & 97.48 & 95.54 & 94.73 & 95.11 \\
\hline Range & 9.53 & 11.72 & 11.54 & 11.58 & 10.28 & 12.5 & 11.39 & 10.77 \\
\hline $\begin{array}{l}\text { Co-efficient of } \\
\text { variation }\end{array}$ & 3.16 & 3.81 & 3.18 & 3.18 & 3.33 & 3.81 & 2.75 & 3.02 \\
\hline
\end{tabular}

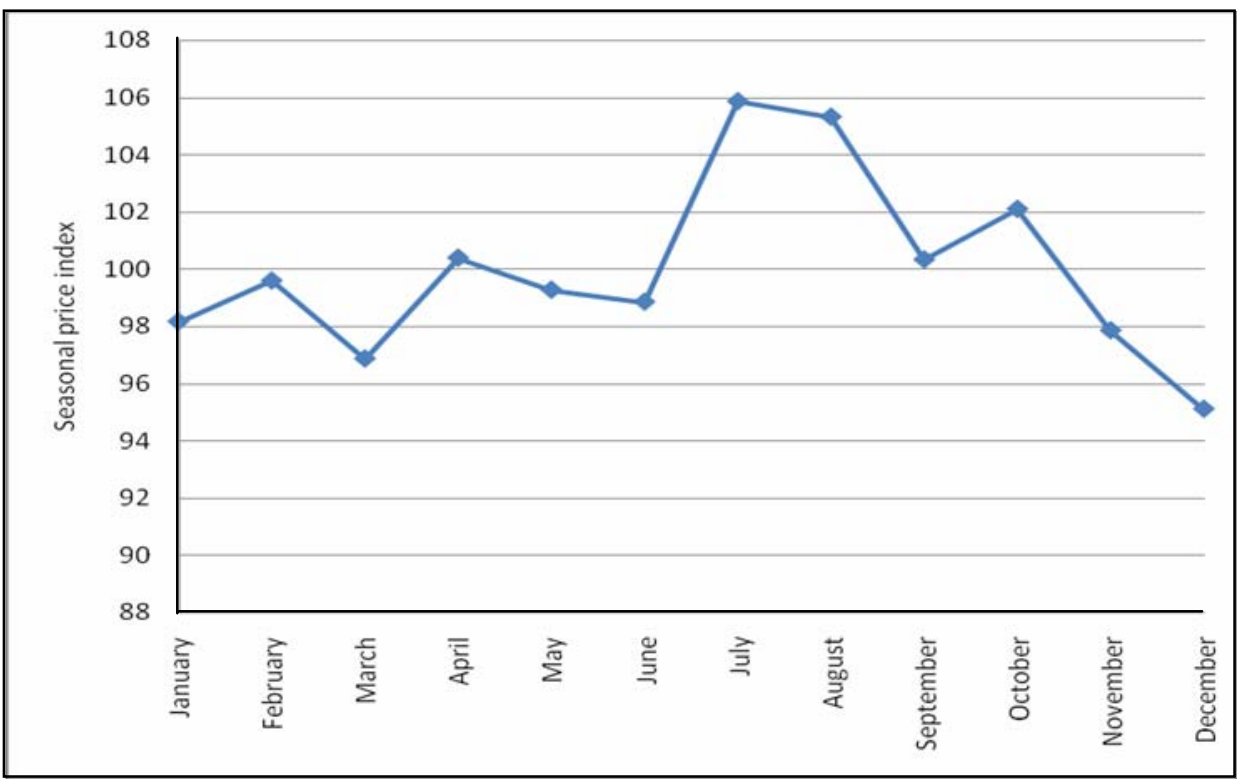

Fig. 2. Average seasonal price variation of egg over seven markets 


\section{Average seasonal price variation of egg in selected markets}

It is observed from table and figure that the highest price index of egg was 105.88 in the month of July and the lowest price index was 95.11 in the month of December. Table 4 also shows that the difference between highest and lowest indices was 10.77 and the co-efficient of variation of monthly price indices of egg was 3.02. In all markets, egg price indices reveal seasonal variation on account of variation in demand and supply in the market.

The causes of such price variation might be-

i. The production of egg varied in different seasons. In winter season, production of egg increases because of congenial climatic condition and the production of egg decreases in summer season because of adverse whether condition.

ii. The cause for a decline in the price (lowest) of egg in December was that the supply of egg was greater in this month. Due to more availability of poultry eggs like indigenous chickens egg, duck egg etc. at this time, the price of egg was the lowest.

iii. Another reason of lower price during April to June was that in those months the demand for egg was lower due to hot weather.

iv. Because of lower production, the price of egg was the highest in July and August. Sometimes, availability of substitute products of egg like fish, meat, duck egg etc. was responsible for fluctuation of price of egg.

v. Many religious festivals such as Ramadan, Eid-ul-Azha decreases the demand for eggs and price fluctuation was found.

\section{Problems and suggestions}

The present study identified some problems and constraints associated with layer farming and egg marketing (Table 5 and Table 7). Some suggestions made by the layer farm owners and traders that are also discussed here (Table 6 and Table 8).

One of the most important constraints to layer farm owners in the study area was the lack of capital. About 80 percent of layer farm owners mentioned this problem (Table 5). This problem was acute because the farmers required quite a substantial amount of money to run the poultry business whether it was layer or broiler farms. Table 5 represents about 86 percent of layer farm owner could not expand their poultry farms due to unavailability of adequate amount of institutional credit.

Higher feed price was one the important constraints which were mentioned by 100 percent layer farm owners. Irregular electricity supply was a major problem of layer farming in the study area. Cent percent farm owners faced this problem, which hampered egg production. Unavailability of medicine and vaccine were reported by the farm owners. They also reported that when medicines were available in the market, they could not buy them because prices are too high. In the study area 100 percent farm owners opined that hartal, strike, and natural calamities caused problems for the smooth transportation system of egg. Most of the owners do not have their own transport. So, they depended on hired transport services and transport facilities were insufficient (86 percent owners reported).

Outbreak of diseases in layer farm is a dangerous problem for the development of poultry farming in Bangladesh. About 90 percent of the layer farm owners reported this problem. Farm owners reported that the environment of the surrounding areas of layer farms is being polluted. The relationships between the owners of farms and neighboring people deteriorate and even the neighboring people often make a quarrel with the owners of the farms due to emission of very bad smell of the farms.

To overcome the difficulties of layer farming and to make the farming more profitable, the farm owners of the study area were asked to suggest solutions to the problems. Some measures were suggested by the layer farm owners for solving the problems identified. Almost 100 percent layer farm owners (Table 6) suggested that the government and non-government organizations should come forward to explore the untapped market for feed in the study areas. Consequently, price would come down through competition in the market. To get rid of the problem of shortage of fund, the provision of short term loan for layer farming should be made on easy terms and conditions by GO and NGOs. All the farm owners also reported that government should take measures to ensure regular supply of electricity to the poultry farms. About 86 percent of the layer farm owners reported that government should establish new veterinary care centers with qualified veterinarian, field assistant and modern logistic supports. And the service should be increased by supplying necessary vaccine and medicine at lower price. 
Table 5. Problems faced by layer farm owners

\begin{tabular}{|l|c|c|c|}
\hline \multirow{2}{*}{ Problems } & \multicolumn{3}{|c|}{ Layer farm owners n=15 } \\
\cline { 2 - 4 } & Number & Percentage & Ranking \\
\hline Lack of capital & 12 & 80.00 & 4 \\
\hline Lack of institutional credit & 13 & 86.66 & 3 \\
\hline High feed prices & 15 & 100.00 & 1 \\
\hline Lack of government support & 15 & 100.00 & 1 \\
\hline Poor quality of feed & 7 & 46.66 & 8 \\
\hline Lack of training facilities & 10 & 66.66 & 5 \\
\hline Insufficient electricity supply & 15 & 100.00 & 1 \\
\hline Non-availability of medicine & 12 & 80.00 & 4 \\
\hline Inadequate supply of vaccine & 10 & 66.66 & 5 \\
\hline Fluctuation of demand & 13 & 86.66 & 3 \\
\hline Breakage of eggs in transit & 15 & 100.00 & 1 \\
\hline Political unrest & 15 & 100.00 & 1 \\
\hline Lack of transport facilities & 13 & 86.66 & 3 \\
\hline High price fluctuation & 14 & 93.33 & 2 \\
\hline Outbreak of diseases & 14 & 93.33 & 2 \\
\hline Problem of natural calamities & 8 & 53.33 & \\
\hline Environment pollution & 9 & 60.00 & \\
\hline
\end{tabular}

Table 6. Measures suggested by the farm owners

\begin{tabular}{|l|c|c|c|}
\hline \multirow{2}{*}{ Suggested measures } & \multicolumn{3}{|c|}{ Layer farm owners n=15 } \\
\cline { 2 - 4 } & Number & Percentage & Ranking \\
\hline Low price of chicks should be available & 13 & 86.666 & 3 \\
\hline Adequate supply of feed at reasonable price & 15 & 100.00 & 1 \\
\hline Government intervention for capital & 11 & 73.33 & 5 \\
\hline Development of disease diagnostic facilities & 13 & 86.66 & 3 \\
\hline Provision of medicine and veterinary service & 12 & 80.00 & 4 \\
\hline Regularity in electricity supply & 15 & 100.00 & 1 \\
\hline Price stability & 14 & 93.33 & 2 \\
\hline Dissemination of market information & 7 & 46.66 & 7 \\
\hline
\end{tabular}

In the study area, the egg traders were found to face various marketing problems at the time of egg marketing. About 100 percent traders (Table 7) reported the problem of breakage and spoilage of eggs, and unfavorable condition caused problems for the smooth transportation system of egg. More than 80 percent traders reported the problem of operating capital and institutional credit in the study area.

Table 7. Problems faced by the egg traders

\begin{tabular}{|l|c|c|c|}
\hline \multirow{2}{*}{ Problems } & \multicolumn{3}{|c|}{ Egg traders $(\mathrm{n}=40)$} \\
\cline { 2 - 4 } & Number & Percentage & Ranking \\
\hline Lack of operating capital & 34 & 85 & 3 \\
\hline Lack of institutional credit & 32 & 80 & 4 \\
\hline Absence of storage facilities & 28 & 70 & 5 \\
\hline Lack of adequate transportation system & 26 & 65 & 6 \\
\hline Breakage and spoilage of egg & 40 & 100 & 1 \\
\hline Price instability & 35 & 87.5 & 2 \\
\hline Political unrest and natural calamities & 40 & 100 & 1 \\
\hline
\end{tabular}

To overcome the problems of egg marketing and to make the business more profitable in the study area, the traders suggested provision of institutional credit, development of storage facilities, adequate market space and facilities, improvement of market information and communication system etc (Table 8).

Table 8. Measures suggested by egg traders

\begin{tabular}{|l|c|c|c|}
\hline \multirow{2}{*}{ Suggested measures } & \multicolumn{3}{|c|}{ Egg traders $(\mathrm{n}=40)$} \\
\cline { 2 - 4 } & Number & Percentage & Ranking \\
\hline Provision of institutional credit & 35 & 87.5 & 1 \\
\hline Development of storage facilities & 34 & 85.0 & 2 \\
\hline Adequate market space and facilities & 32 & 80.0 & 3 \\
\hline Improvement of market information & 26 & 65.0 & 5 \\
\hline Communication system & 29 & 72.5 & 4 \\
\hline
\end{tabular}




\section{Conclusion}

In egg marketing system, five channels were identified in the study area. In these channels the product moved from the producers to the ultimate consumer through some marketing intermediaries such as arathder, wholesaler, wholesaler cum retailers and retailers. All farm owners sold their eggs to arathder. Arathder sold their eggs to wholesaler; wholesaler sold their eggs to wholesaler cum retailers and retailers. About 90 percent of retailers purchased eggs from wholesaler and rest of the 10 per cent purchased from wholesaler cum retailer. Retailers sold their entire volume of eggs directly to the ultimate consumers.

The average marketing cost of farm owners were estimated at Tk. 3.23 for one hundred eggs. The average costs of egg marketing for arathder, wholesaler, wholesaler cum retailers and retailers were estimated for 100 eggs at Tk. 20.60, Tk. 16.34, Tk.13.09 and Tk. 12.51, respectively. The average gross margins for arathder, wholesaler, wholesaler-cum-retailer and retailer were Tk. 30, Tk. 30, Tk. 35 and Tk. 45 per 100 eggs. The average net margins for arathder, wholesaler, wholesaler-cum-retailer and retailer were estimated Tk. 9.40, Tk. 13.60, Tk. 21.91 and Tk.32.50per 100 eggs respectively. The average seasonal price indices of egg in Gazipur market during the period of 2000 to 2011 was the highest 105.88 in the month of July and the lowest 95.11 in the month of December. The price index was lowest in the month of December because of higher supply of egg in this month and more availability of indigenous chicken egg, duck egg etc at this time. The prices were higher in July because of lower production. The present study identified some problems and constraints associated with layer farming and egg marketing.

It was observed from the marketing margin analysis that egg marketing was a profitable business. The findings, therefore, suggest that there is a wide scope for the development of layer farming and egg trading in this country. Development of this enterprise is helpful in employment generation and poverty alleviation of the country. On the basis of the findings of this study, some recommendations are put forward with a view to improving the production as well as marketing of egg in the study area.

i. Government should take appropriate policy for ensuring steady supply of quality feed at reasonable price and day old chicks to the farm owners

ii) Training needs to improve technical knowledge and management skill of the farm owners

iii. Financial institutions and NGOs should provide credit facility at easy terms and conditions to the layer farm owner and egg traders to meet cash need

iv. Regular electricity supply should be ensured to operate the layer farming and egg trading

v. Communication and transportation system must be developed to increase the efficiency of egg marketing system. Adequate transportation facilities should be made available for carrying egg from farm yard to market for reducing wastage of egg

vi. Strict policy needs to be formulated to protect the infant industry from the effect of price instability and demand fluctuation.

The study also recommends that the expansion of layer farming and egg marketing is necessary for the creation of employment both in rural and urban areas. Government, private entrepreneurs and different NGOs can play an important role for development of egg production and marketing in the country.

\section{References}

Acharya, S.S. and Agarwal, N.L. 1999. Agricultural Marketing in India. 4th Edition, Oxford and IBH Publishers, Calcutta.

Bangladesh Bureau of Statistics (BBS). 2000. Statistical Year Book of Bangladesh. Ministry of Planning, Government of the People's Republic of Bangladesh, Dhaka.

Ministry of Finance (MoF). 2011. Bangladesh Economic Review. Finance Division Government of the People's Republic of Bangladesh, Dhaka.

Government of Bangladesh (GoB). 2010. Report on the Economic Survey of Bangladesh. Ministry of Finance, Ministry of Planning, Government of the Peoples Republic of Bangladesh, Dhaka.

Khan, R.M. and Roy, C.P. 2006. "Credit Policy, Disbursement and its Impact on Poultry Industry in Bangladesh." Presented in Third International Poultry Show and Seminar, February 28-March 2, 2006, Organized by Worlds Poultry Since Association, Bangladesh Branch, Dhaka.

Patniak, K.U.S. 1989. Efficiency of Groundnut Marketing in India. 1st Edition. Discovery Publishing House, Delhi, India.

Tomek, W.G. and Robinson, L.K. 1990. Agricultural Product Prices, London, Cornell University Press. 